\title{
Surface water management model for the Colorado River Basin
}

\author{
H. Sanvicente-Sánchez ${ }^{1}$, E. González ${ }^{1}$, C. Patiño ${ }^{1}$ \\ \& A. Villalobos ${ }^{2}$ \\ ${ }^{I}$ Mexican Institute of Water Technology, Mexico \\ ${ }^{2}$ Autonomuous University of Zacatecas, Mexico
}

\begin{abstract}
The Colorado River Basin is a complex system of water resources, operated to meet multiple objectives and to satisfy two treaties, an interstate one into the United States and also an international treaty between Mexico and the United States. At the beginning of this century (2000-2004), an intense drought caused that the U.S. Bureau of Reclamation (USBR), who operates the system, began an investigation to establish rules that would let operate the system in conditions of scarcity. This study finished in December of 2007 and proposed a number of operational alternatives, which have been implemented in the "Colorado River Simulation System" (CRSS) that works at the RiverWare platform, but that just cover the United States portion of the binational Colorado River Basin. Based on this work, the National Water Commission of Mexico (CONAGUA) recognizes the importance of having a model equivalent to the CRSS, but including both the Mexican and U.S. sides. Then, Mexico would be in the possibility to evaluate water management alternatives proposed by the USBR. Additionally, the CONAGUA, the International Boundary Water Commission (CILA), and Mexican water users could perform their own analysis for the Mexican area. This paper presents the description of the general operational rules for the whole Colorado River Basin, as well as its implementation in the "Water Evaluation and Planning System" (WEAP) platform.
\end{abstract}

Keywords: water management, Colorado River Basin, WEAP platform, transboundary river basin management. 


\section{Introduction}

The Colorado River is a complex water system, which is operated to meet multiple objectives such as: irrigation, power generation, urban use, industrial, recreation, etc., which are often conflicting and competing for use of water. The dams operation in the Colorado basin is managed by the U.S. Bureau of Reclamation (USBR) [1] and is strictly governed to meet the "Colorado River Compact", an interstate water distribution treaty, dating back to 1922, among seven U.S. states that cover part of the basin (Wyoming, Utah, New Mexico, California, Arizona and Nevada) and the International Water Distribution Treaty between Mexico and United States that was signed in 1944 (in Mexico the water is distributed between Baja California and Sonora states).

Since the signing of the Colorado River Compact in 1922, negotiated during a period of relatively high runoff, the basin has experienced continuous development resulting in a sustained increase in the demands until the present. Additionally, a particularly intense drought, occurred from 2000 to 2004, led the system to a critical condition in which the treaties are not likely to be satisfied. This provoked that the USBR to conduct a study of possible policies for operation in conditions of scarcity and to enter into negotiation with users of the waters of the Colorado River in order to adopt formal rules of operation for these conditions in the lower basin. This study finished in December of 2007 and it proposed a number of operational alternatives [2], which have been implemented in the "Colorado River Simulation System" (CRSS) a computational model that works at the RiverWare platform.

The computational models are capable of representing the diverse nature and complexities of a basin, becoming powerful tools to facilitate effective planning of the operation of water resource systems. The exploration of different policy rules for reservoirs, the evaluation and revision of these, by modeling, is essential to ensure that operations can respond to changing hydrological conditions and management of river water. The planning model Official for the USBR is the "Colorado River Simulation System (CRSS), unfortunately this model does not include the Mexican side of the basin. Mexico is considered as a user that demands the water volume established in the International Treaty of 1944.

This work aimed that Mexico should have a model equivalent to CRSS, and that to this new model should include both Mexican and U.S. sides. So, Mexico could evaluate the alternatives of operation selected by the USBR. Additionally the National Water Commission (CONAGUA) of Mexico, the International Boundary Water Commission (CILA) of Mexico and the water users in Mexico could perform their own analysis for the Mexican area.

\section{Objective}

The main objective is develop a simulation model for surface water management for the whole Colorado River Basin (both United States and Mexican sides) to allow analyze different operation strategies for the water system. A secondary 
objective is transferring the model and its results to users. The model will be developed in the system modeling WEAP (Water Evaluation and Planning System) and the part of the basin within the United States will be compatible with the Colorado River Simulation System (CRSS), developed in RiverWare.

\section{Colorado River basin description}

The Colorado River was born in the U.S. Rocky Mountains; has a length approximately of 2,253 $\mathrm{km}$ and descends $3,657.6 \mathrm{~m}$ from its birth to the sea in the Gulf of California in Mexico. The river basin drains approximately 629,367 $\mathrm{km}^{2}$, which represents one twelfth of the territory of the United States of America and includes parts of seven states in this country and two in Mexico (fig. 1).

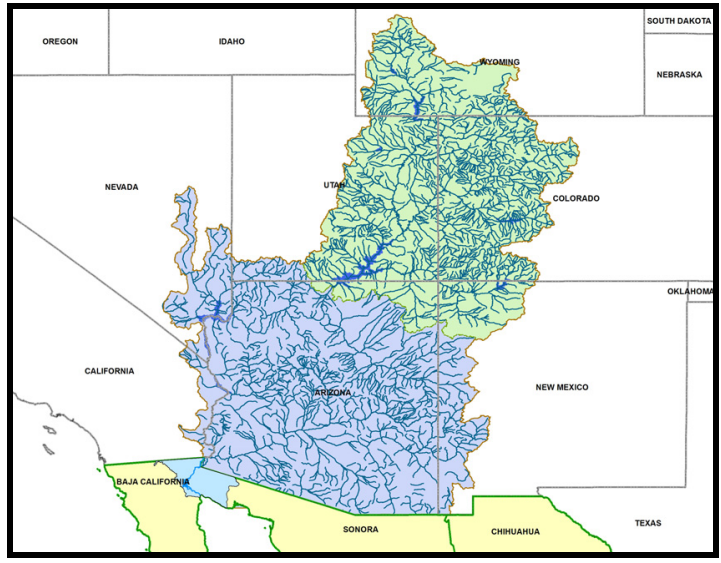

Figure 1: Colorado River Basin location.

The basin is divided, physically and politically by the Colorado River Compact, in upper basin and lower, being the hydrometric station "Lees Ferry", at Arizona, point divisor. The Colorado River Compact in 1922, granted to each of the basins (upper and lower) $9251.25 \mathrm{Mm}^{3}$ annual share of water among the states that make up. Subsequently, the International Water Distribution Treaty between Mexico and United States of 1944 gave $1850.223 \mathrm{Mm}^{3}$ more water to the lower basin for delivery to Mexico. Table 1 shows the current distribution of water in the Colorado River basin.

Table 1: $\quad$ Colorado River basin water distribution.

\begin{tabular}{|c|c|c|c|}
\hline $\begin{array}{c}\text { State } \\
\text { (upper basin) }\end{array}$ & $\begin{array}{c}\text { Percentage of water } \\
\text { assigned }\end{array}$ & $\begin{array}{c}\text { State } \\
\text { (lower basin) }\end{array}$ & $\begin{array}{c}\text { Volume } \\
\left(\mathbf{M m}^{\mathbf{3}}\right)\end{array}$ \\
\hline Wyoming & $14.00 \%$ & California & $5,427.320$ \\
\hline Utah & $23.00 \%$ & Arizona & $3,453.749$ \\
\hline Colorado & $51.75 \%$ & Nevada & 370.045 \\
\hline Nuevo México & $11.25 \%$ & México & $1,850.223$ \\
\hline
\end{tabular}


An average of $90 \%$ of annual river runoff is generated in the upper basin. The runoff remaining is generated by inputs from tributaries and extreme rainfall events in the lower basin. The annual contributions of the tributaries of the lower Colorado River are approximately 1,702.205 $\mathrm{Mm}^{3}$, excluding the Gila River intermittent flows.

The runoff in the basin is characterized by significant temporal variability. The annual natural runoff has varied in "Lees Ferry" from $6,537.454 \mathrm{Mm}^{3}$ to $28,370.082 \mathrm{Mm}^{3}$ during the historical record from 1906 to 2003, with an annual average runoff of $18,625.576 \mathrm{Mm}^{3}$, approximately. However, rarely since the signing of the Colorado River Compact, the annual average runoff on 10 years has been equal to $18,502.228 \mathrm{Mm}^{3}$ of water volume assigned in 1922 , and to $20,352.451 \mathrm{Mm}^{3}$ of water volume distributed from 1944 until nowadays [2].

There are over 90 reservoirs in the Colorado River basin, with a total storage capacity of more than $74,010 \mathrm{Mm}^{3}$, about four times the annual average runoff. However, $85 \%$ of the total storage is contained in two reservoirs, Lake Mead (formed by Hoover Dam) and Lake Powell (formed by Glen Canyon Dam). The arid climate of the region leads to loss by evaporation of $2467 \mathrm{Mm}^{3}$ of water per year, approximately, from reservoirs [1]. The construction of large storage facilities such as the Hoover Dam in 1936 indicates that the first users of the river water had forecast that the drought was an inevitable part of the future of the basin [3].

The reservoirs in the upper basin (Powell on Colorado river, Navajo on San Juan River, Fontenelle and Flaming Gorge on Green River and the unitary dams system Wayne N. Aspinall formed by Crystal, Morrow Point, Blue Mesa and Taylor Park on Gunnison River) provide approximately 38,485.2 $\mathrm{Mm}^{3}$ storage from which 29,974.05 $\mathrm{Mm}^{3}$ corresponds to Powell. These reservoirs are operated to provide to upper basin users with a secure supply of water and delivering water to Powell. Glen Canyon is the last dam on the Colorado River for the upper basin and controls almost all the flows coming out of this area. In 1996, a maximum limit of $707.92 \mathrm{~m}^{3} / \mathrm{s}$ was established on withdrawals from Glen Canyon, except during periods of high availability. Under a maximum extraction of $707.92 \mathrm{~m}^{3} / \mathrm{s}$, the maximum operating capacity is limited to 1,048 MW [2].

The reservoirs of the lower basin are operated primarily to facilitate the demands delivery water and regulate runoff. Lake Mead provides the largest part of storage and control for the Colorado River in this lower basin. The power generation plant of the Hoover dam has a maximum capacity of 2,074 MW through seventeen units; the energy produced is sold and divided between Arizona, Nevada and California. Glen Canyon and Hoover contribute about $3.6 \%$ of the total generating capacity of the seven federal states of basin [4].

Davis dam, which forms Lake Mohave, provides additional control for the volumes assigned to Mexico (1,850.223 $\mathrm{Mm}^{3}$ of water per year). During high levels of water, the reservoir extends until the discharge channel of Hoover dam. Davis dam was built by the U.S. government as part of the agreements resulting from the signing of the Treaty of International Waters between U.S. and Mexico, where also was agreed the construction of the Morelos dam in Mexico to divert the major part of the Mexican water. 
Downstream of Davis, the Parker dam, which fills Lake Havasu, was used mainly to pump water to the cities of Los Angeles and San Diego, California; and to pump water to Arizona. The water is delivery to California through the aqueduct "Metropolitan Water District of Southern California" (MWD) and to Arizona through the aqueduct "Central Arizona Project" (CAP).

The Imperial dam is the main water diverter towards irrigation projects in the United States, here are born the All American Canal, which supplies the Imperial and Coachella Valleys, and the Main Gila Gravity Canal, which supplies water to the Yuma Valley in Arizona.

The Mexican structure to divert water is Morelos Dam, which is located immediately downstream of the Northern International Boundary between Mexico and U.S. and is responsible for supplying water to the northern Baja California region that includes the cities of Mexicali, Tecate and Tijuana, as well as the agricultural valleys of Mexicali, BC and San Luis Rio Colorado, Sonora, through a system of canals that go beyond the $2,700 \mathrm{~km}$ of length.

\section{Methodology}

\subsection{WEAP revision}

WEAP [6] (fig. 2) is a system which integrates hydrological processes in a basin with the water resources management, distinguished by its approach to managing supply and demand and because works on the principle of balance water. WEAP is applicable to different levels of study, a local watershed, a region or a water resources system complete. WEAP can easily develop scenarios to explore potential water management across different hydrology.

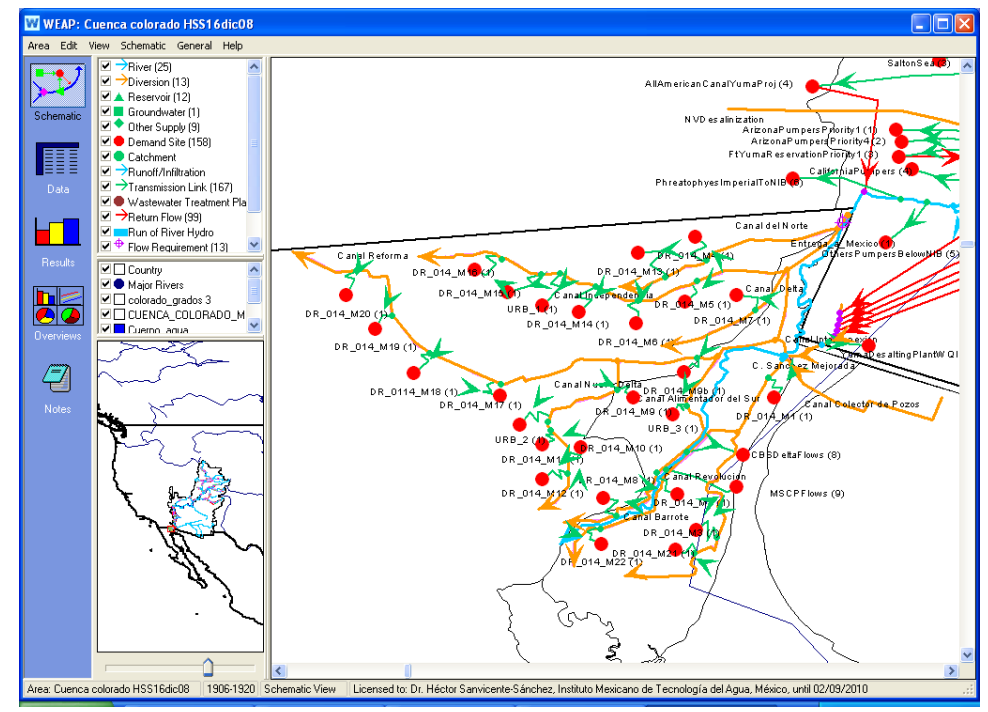

Figure 2: $\quad$ WEAP user interface, Colorado model (Mexican part). 
The building of a WEAP model includes several steps: Define time step to use (daily, monthly, yearly, etc.), set the limits or space boundaries for the area to simulate, establish the system components (build the system schema), configure the problem (feed all the data and system information) and finally, make a model validation. The initial year (which is named current account in WEAP) and the reference scenario provide a picture of current conditions of the system (water demand, pollution loads, infrastructure, resources and supplies, etc.) and their behavior over time as if nothing changed. The future scenarios are developed using alternative sets of technological assumptions, infrastructural and policies for resources management.

The information required for modeling the management of surface water in an area in WEAP is: rivers or main streams, points of diversion, reservoirs, demand sites, lines of conduction between demand sites and sources, return flows, rights, consumption, losses, ecological flow requirements, hydrometric records, etc.

\subsection{Colorado River Simulation System (CRSS)}

The Colorado River Simulation System (CRSS) [6] is a computational model developed by the USBR to manage the Colorado River Basin system and explore various policies for reservoirs operation through the simulation, it is essential to ensure that a policy rule will be able to respond to the changing hydrological conditions in the basin. CRSS model runs in RiverWare (fig. 3).

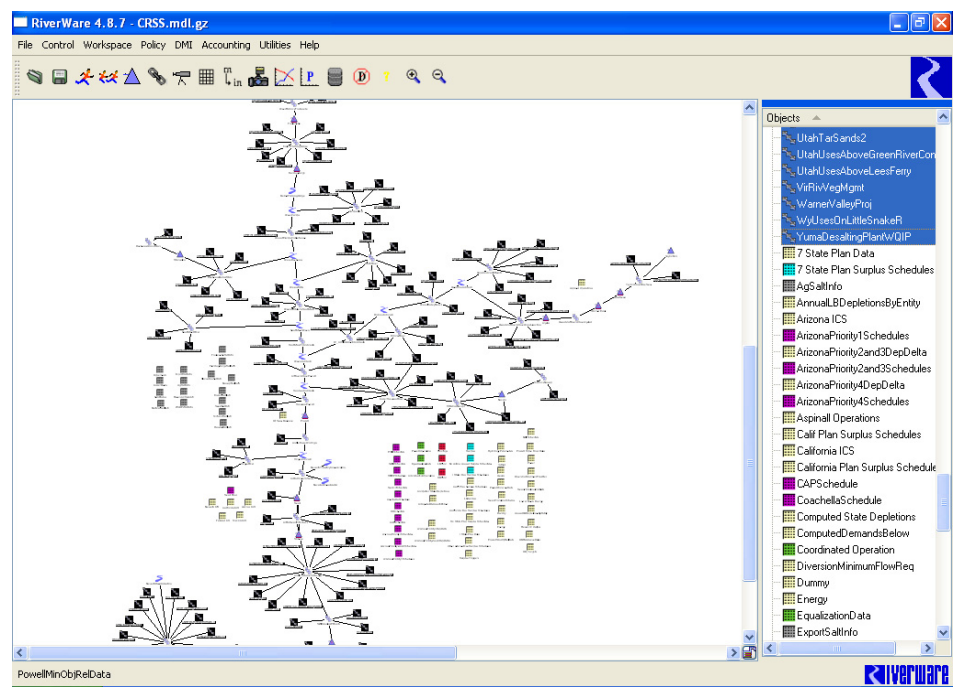

Figure 3: $\quad$ CRSS model in RiverWare.

RiverWare is a general toolkit to model a river basin. It permits to evaluate the operational policy in a system and optimizes it, accounts water, manages water rights and plans a long-term resource. RiverWare was designed specifically to facilitate the implementation of various policies of operation, 
instead of being embedded in the computational model can be read attachments so as to facilitate comparison of the behavior of the system by using a given set of rules.

CRSS model is displayed graphically using a diagram to synthesize the broad components, which are selected from a palette of elements that has the RiverWare; thereafter, defining characteristics of the elements and bind to create the topology of the basin [7]. The CRSS published in the Final Environmental Impact Statement (FEIS) [2] simulates operation rules in Lakes Powell and Mead, mainly, and considers the basin within the United States, only.

\subsection{Basic information}

\subsubsection{Streams}

Hydrography maps were obtained from the National Hydrography Dataset (NHD) web page, from where the Geodatabases for the USGS hydrologic units 14 and 15 that cover the Colorado River Basin were downloaded. Another source was the USEPA (U.S. Environmental Protection Agency) web page, where the file named EPA Reach File 1 was downloaded. For the Mexican basin part, hydrography maps and information of canals were obtained from the National Institute of Statistics, Geography and Informatics (INEGI) and CONAGUA. Subsequently through a Geographic Information System (GIS) the hydrography network was filtrated to get the major rivers (fig. 4). Among the major tributaries of the Colorado River are: Green, Yampa, San Juan, Duchesne, and Gunnison Gila.

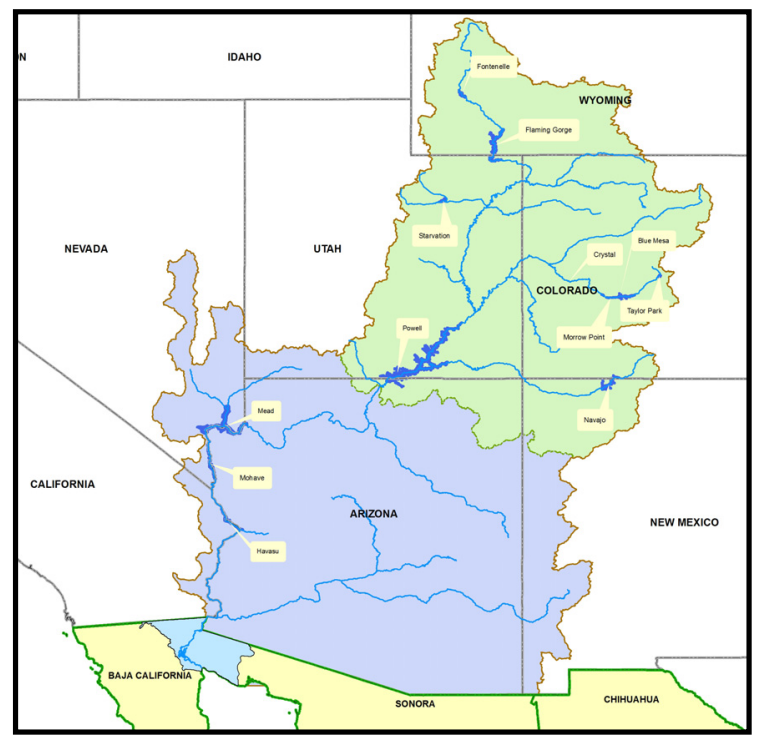

Figure 4: $\quad$ Major rivers and reservoirs, Colorado River Basin. 


\subsubsection{Reservoirs}

Figure 4 also shows the locations of the 12 reservoirs considered in the model (Fontenelle, Flaming Gorge, Taylor Park, Blue Mesa, Morrow Point, Crystal, Navajo, Starvation, Powell, Mead, Mohave and Havasu). Information for the reservoirs was extracted from CRSS and FEIS [2] (storage capacity, monthly net evaporation rate, volume-elevation curve, etc.). Must be noted that the actual operation policies and those ones considered as alternatives for handling shortages are set out in FEIS [2].

\subsubsection{Demand sites}

Based on the information contained in the CRSS, 134 demand objects were identified (fig. 3) that represent 133 water-user groups in the Colorado basin for the U.S. (the last group is Mexico). For each of these user groups, its water rights, monthly variation water needs, water consumption and losses was gotten from the CRSS. To Mexico, the volume set at the International Water Distribution Treaty was the minimum flow requirement and delivered into the canal network. Once in the canal network, the water is distributed to different users: agricultural modules, major cities (Mexicali, San Luis Rio Colorado and aqueduct Tijuana-Tecate) and rural populations clustered. The information for Mexican demand sites was obtained from CONAGUA.

\subsubsection{Diversions, transmission links and return flows}

The diversion points from streams to demand sites and return points from demand sites to streams (if present) were not precisely located geographical. They were located depending on the stream where demand site takes or returns water and the appearing order on it to maintain the availability of liquid for users who are supplied by ramifications downstream. A drift towards demand site is setting in WEAP through a transmission link that goes from the source to the demand site and determining its physical restrictions. It should be mentioned that a demand site may have more than one water source and thus it must have more than one transmission link case in which supply preferences are set or water volumes allocated from each source of supply. A demand site can have or not a return flow or to have more than one. For each demand site, we got the water volumes assigned to each source of supply, their preferences and their returns.

\subsection{Colorado River Basin WEAP Model}

\subsubsection{System schema}

The maps collected were processed into a GIS to obtain the following maps (in shapefile format): basin limit, state boundaries, main streams, water bodies (reservoirs), canals in the Mexican area, hydrometric stations, etc. These maps were loaded onto WEAP and were used to build the schematic diagram of the system (system schema). Rivers and canals were digitized to create the drainage network (fig. 5). Subsequently, reservoirs were incorporated using as reference the water bodies' map and finally demand sites with its transmission link and return flow were added (fig. 5). 


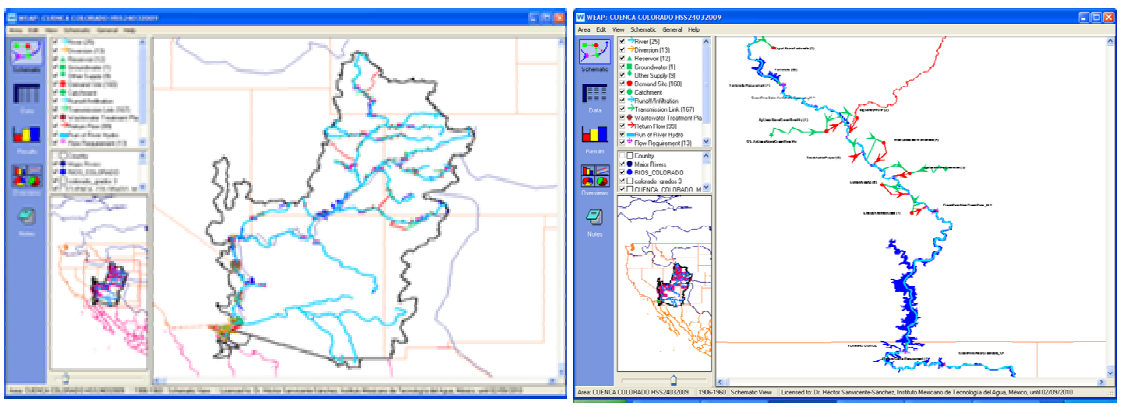

Figure 5: $\quad$ WEAP schema for Colorado River Basin.

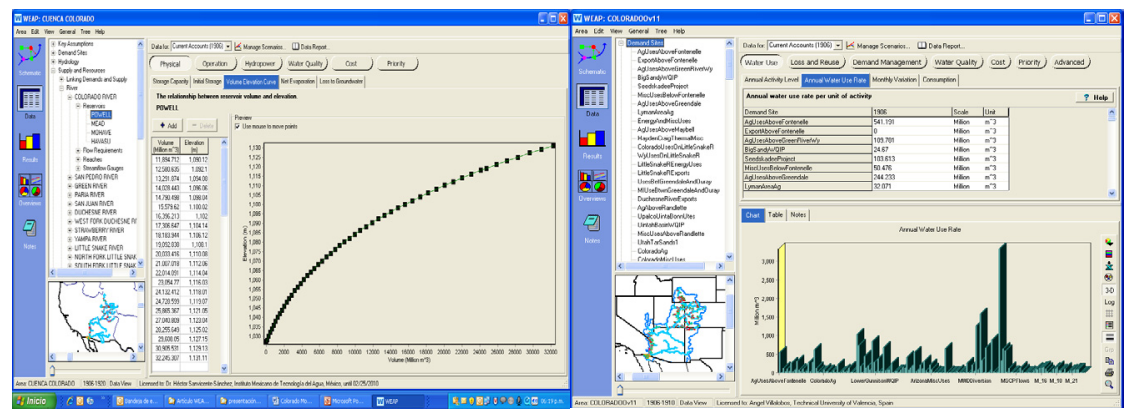

Figure 6: Reservoir and demand sites water use information.

In WEAP, stream network and all the system components have to be reproduced as they are in reality into the system schema. The system schema is a simplified reality representation which preserves the spatial relationships for the system.

\subsubsection{Feeding information}

Once the system schema is built, the next step is to feed the model with the information for the various elements that are contained in it (headflows, local flows, reservoir information, transmission links, water rights, water use at the sites of application, etc.).

The model was fed by 29 series of historical naturalized runoff (1906-2005), of which 14 are head flows for rivers: Green, Yampa, Strawberry, White, Colorado, Dolores, San Juan, Taylor Park, San Rafael, Virginia, Paria, Little Colorado, Little Snake, Bill Williams. The remainder is local runoff located downstream from dams or intermediate portions of the network. Flows for the local hydrometric stations were located and are clearly defined where they should be fed in WEAP. The series were obtained from the CRSS.

With regard to the storage infrastructure, WEAP requires both physical characteristics (storage capacity, initial storage, elevation-capacity curve, 
monthly net evaporation rate) as the operating characteristics (level of maintenance, level of inactivity, level buffer to restrict extractions) (fig. 6)

Demand sites were fed with the information about the water use: Annual activity level, Annual water use rate, monthly variation and consumption (fig. 6)

\subsubsection{Reservoir operation rules}

The operation rules for the dams that are incorporated in the WEAP model were those ones given in the "No action" alternative of the FEIS [2], which establishes the actual operating rules for the system. the operation rules were programmed within the "Key Assumptions" of WEAP. These rules originally set the outputs flow for dams, but through the balance equation, they are used to control the storage level in reservoirs. We use the operating variables for a reservoir that has the WEAP to fix the storage (fig. 7).

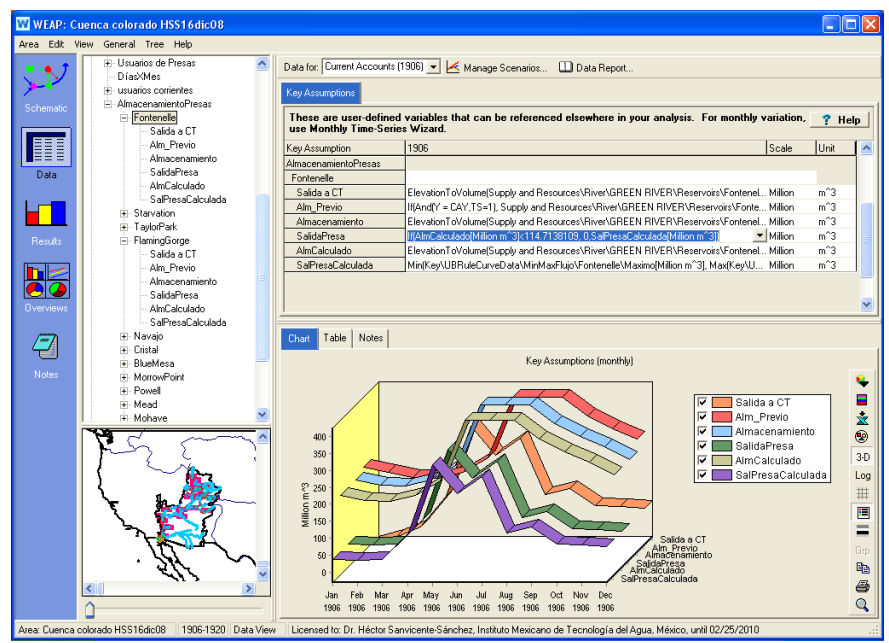

Figure 7: Reservoir operation rules.

\section{Model validation}

The model validation was carried out comparing the results obtained by the WEAP model constructed in this study against one CRSS execution via RiverWare.

The criteria for evaluating the model were:

a. Flow along the main channel and tributaries

b. Storage and output flow from reservoirs

c. Delivery of water to different users

The comparative analysis throws correlation factors above 0.9 for all the reservoirs and for the users surveyed. Below are examples of the results

Figure 8 shows a comparison of the storage and output flows for Fontenelle between the WEAP model and the CRSS executed in RiverWare (RW). 


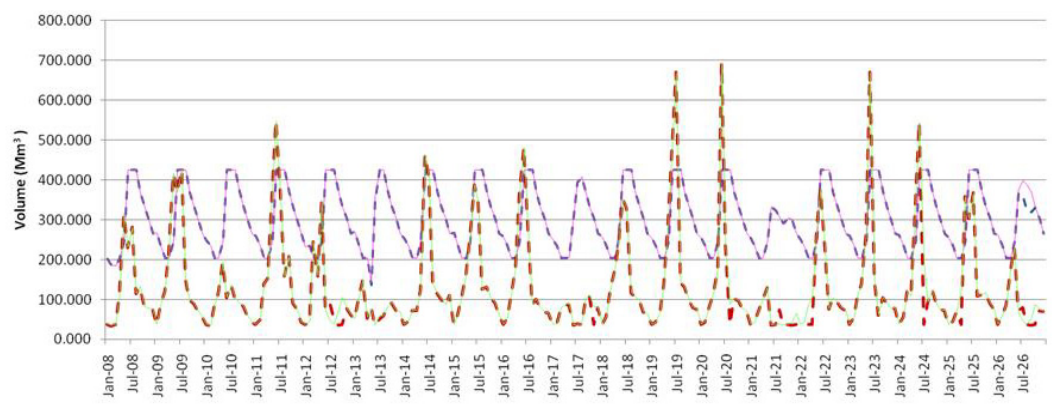

- - - Storage Weap —-Storage RiverWare - - Outflow_Weap_— Outflow_RiverWare

Figure 8: $\quad$ Storage and output for Fontenelle (2008-2026).

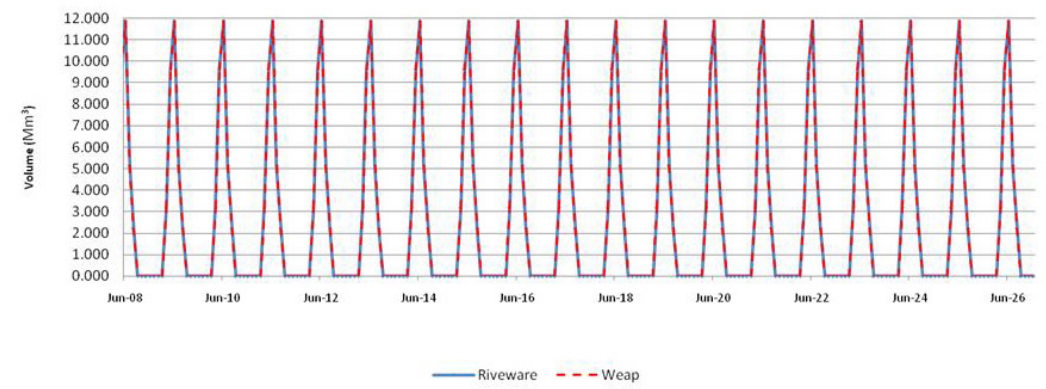

Figure 9: $\quad$ Water delivery to LymanAreaAG demand site.

Figure 9 shows the supply of water to the user group called LymanAreaAg (grouping of users in the Lyman area) located on the Green River downstream from Fontenelle.

The examples illustrated in Figures 8 and 9 clearly show the high correlation between the results delivered by the CRSS and the WEAP model developed. It is noteworthy that differences are mainly in reservoirs as shown in Figure 8 for the year 2026 and not on meeting the demand or supply of water to users (Fig.9), however, these differences are small and they are rapidly absorbed in two or three steps of time (months) which allows joining the curves again

\section{Conclusions}

The Colorado River is a clear example of a complex water system in which there are diverse sources of supply and large numbers of users. In addition to a strong legal framework that governs its operation.

Use of simulation models such as the WEAP allows representing the diverse nature and complexities of a watershed, becoming powerful tools to facilitate effective planning of the operation of water resource systems. 
The system of dams on the Colorado River is managed by the U.S. Bureau of Reclamation of the United States of America, and is governed strictly in accordance with the law of the river, a series of documents dating from 1922. However, for the Mexican government is very important to have a simulation model for managing water resources in the whole Colorado River Basin, including both Mexican and the USA sides, in order to facilitate decision making and to review operational rules proposed by the USBR.

\section{Acknowledgments}

The authors would like to express appreciation to the National Water Commission of Mexico (CONAGUA) and the Mexican National Council for Science and Technology (CONACYT), who supporting this project.

\section{References}

[1] Jerla, C. S., An analysis of coordinated operation of Lakes Powell and Mead under lower reservoir conditions, Masters Thesis, University of Colorado, pp. 176, 2005.

[2] USBR, Final Environmental Impact Statement, Colorado River Interim Guidelines for Lower Basin Shortages and Coordinated Operations for Lake Powell and Lake Mead, U.S. Department of the Interior, Bureau of Reclamation, Upper and Lower Colorado Regions, Boulder City, NV, Vol-1 pp. 575, Vol-2 pp. 319, Vol-3 pp. 206, Vol-4 pp. 828, 2007.

[3] MacDonnell, L.J., Getches, D.H. \& Hugenberg, W.C., The Law of the Colorado River: Coping with Severe Sustained Drought, Water Resources Bulletin, 31(5), pp. 825-836, 1995.

[4] USBR, Colorado River Interim Surplus Criteria, Final Environmental Impact Statement, U.S. Department of the Interior, Bureau of Reclamation, Lower Colorado Region, Boulder City, NV, Vol-1 pp. 36, Vol-2 pp. 217, Vol-3 pp. 305, 2000.

[5] Sieber, J. \& Purkey, D, Water Evaluation and Planning System (WEAP): User's Guide, Stockholm Environment Institute (SEI), US Center, Somerville, MA, pp. 211, 2007.

[6] Fulp, T.J., Colorado River Operations, Proc. Of the $1^{\text {st }}$ Climate Change Symposium, eds. Cooperative Institute for Research in Environmental Systems (CIRES), Boulder, CO., 1999

[7] Zagona, E.A., Fulp, T.J., Shane, R., Magee, T.M. \& Goranflo, H.M., Riverware: A generalized tool for complex reservoir system modeling, Journal of American Water Resources Association, 37(4), pp. 913-929, 2001 . 